\title{
Application of a robust microplate assay to determine induced $\beta-1,3-$ glucanase and chitinase activity in the cotton plant
}

\author{
Muhammad Fahad Khan' \& Ummad-ud-din Umar*,1 (iD \\ ${ }^{1}$ Department of Plant Pathology, Faculty of Agricultural Sciences \& Technology, Bahauddin Zakariya University, Multan, 60800, Pakistan; *Author for correspondence: \\ ummad.umar@bzu.edu.pk
}

BioTechniques 70: 203-208 (April 2021) 10.2144/btn-2020-0015

First draft submitted: 3 February 2020; Accepted for publication: 5 January 2021; Published online: 29 January 2021

\section{ABSTRACT}

Resistance is induced in cotton plants as the result of either viral infection or exogenous application of elicitors. Induced resistance can be evaluated by determining the production of $\beta-1,3-$ glucanase and chitinase in plants as a biochemical parameter. The assays being used for the determination of chitinase and $\beta$-1,3-glucanase activity are laborious and not cost-effective, as the reducing sugars produced by the substrates colloidal chitin and laminarin are very expensive. The concentration of both substrates was standardized and reduced to $0.25 \%$ from $4 \%$ in a modified microplate assay, which appeared to be more effective. The amount of $\beta$-1,3-glucanase and chitinase produced was significant and determined by the new modified assay. The sensitivity of the microplate assay was significantly raised approximately one- to twofold.

\section{METHOD SUMMARY}

The existing procedure for determining resistance induced in cotton plants by viruses and elicitors is time-consuming and expensive. However, this resistance can be determined by $\beta$-1,3-glucanase and chitinase activity through a modified, cost-effective and robust technique. Here the authors present a 96-well polystyrene microplate assay, instead of a quartz cuvette assay, in which a decreased amount of costly substrates was used and a large number of samples were processed in a short time.

\section{KEYWORDS:}

\section{$\boldsymbol{\beta}$-1,3-glucanase $\bullet$ chitinase $\bullet$ cotton $\bullet$ elicitors $\bullet$ microplate assay}

Plants have specific mechanisms against infection through their defense responses. Chitinases, polyphenol oxidases, glucanases, proteinase inhibitors and other pathogenesis-related (PR) proteins are produced as a result of induced defense responses and act as a physical barrier to pathogens [1]. A wide range of phytopathogenic organisms attack plants, and these enzymes and proteins play a significant role in enhancing the defense-related mechanisms against them [2]. Viruses, fungi, bacteria, animals and plants are inhibited by chitinases, whereas $\beta$-1,3-glucanase has a vital role in a variety of developmental processes and defensive behaviors of plants against pathogens. The inhibitory action of plant chitinases is achieved either by direct hydrolysis of the chitin in fungal cell walls or by releasing polysaccharide oligomers, stimulating plant defense reactions [1,2]. Based on amino acid sequence similarity, chitinases are classified into two glycosyl hydrolase families: 18 and 19. Family 19 chitinases are generally found in plants and some bacteria, whereas family 18 chitinases are found in a broad range of organisms, including viruses, bacteria, fungi, animals and plants [3]. There have been only a few reports of bacterial chitinase expression in plants [4,5]. The $\beta-1,3$-glucanase gene family is involved in a wide variety of plant physiological developmental processes as well as pathogen defense mechanisms. The hydrolysis of 1,3- $\beta$-D-glucosidic linkages in $\beta$-1,3-glucans is catalyzed by the enzymes of $\beta-1,3$-glucanases and is widely found in bacteria, fungi and viruses. However, plant $\beta-1,3-g l u c a n a s e s$, classified as the PR-2 family of PR proteins, have been proposed to defend against pathogen infection in two ways: by hydrolyzing $\beta$ 1,3-glucan, a major structural component of fungal cell walls, and by promoting the release of cell wall-associated elicitors that further stimulate defense reactions [6]. Infection of resistant plants with viruses triggers a local hypersensitive reaction in the host [7], which is thought to block the systemic spread of the virus and result in a local lesion response. Callose, a (1 $\rightarrow 3)$ - $\beta$ - $d$-glucan [8], is deposited between the plasma membrane and cell wall as part of the hypersensitive reaction to infection by fungi [9] and viruses as well as in response to abiotic stresses [10]. Therefore, $\beta$-1,3-glucanases play a role in affecting the pathogenicity of viruses [7].

The enzymatic activity of $\beta-1,3-$ glucanase and chitinase can be deployed as a biochemical marker for evaluating resistance. This is determined not only for plants [11,12] but also for microbial preparations [13,14]. To determine $\beta-1,3-$ glucanase activity, a technique developed by Dygert et al. has been used widely [15]. To overcome the problem of copper oxidation during measurement, Zheng and Wozniak developed a robust microplate assay capable of measuring $\beta-1,3-$ glucanase activity in 20 tobacco plant samples within $1 \mathrm{~h}$ [16]. In addi- 
tion, as a substitute for an expensive cuvette assay, a microplate assay was developed to estimate $\beta$-1,3-glucanase activity in microbial preparations using 3,5-dinitrosalicylic acid (DNS) reagent as an oxidant [17]. DNS reacts with the carbohydrates in an alkaline solution with ketone or aldehyde groups. The concentration of the reductant directly affects the depth of color within a specific concentration range, that is why reducing sugars in plants and animal feed are widely determined by DNS [18].

Cotton plants were used in this experiment for the optimization of an assay to determine $\beta-1,3-g l u c a n a s e$ and chitinase. Enzymatic activity of $\beta$-1,3-glucanase and chitinase in cotton plants was induced through the inoculation of Cotton leaf curl virus (CLCuV) and exogenous application of elicitors like salicylic acid (SA) and benzothiadiazole (BTH).

CLCuV is a geminivirus transmitted by the whitefly (Bemisia tabaci Genn.) [19-22] and is well known for causing major losses to cotton production in Pakistan. The virus contains ssDNA with two geminate particles. The symptoms of CLCuV are upward and downward curling of the leaves, with small and large vein thickening. A leaflet structure known as enation, appearing on the underside of the leaf, is a characteristic symptom of the CLCuV Multan strain [23]. CLCuV acts as a "helper virus" for two dissimilar types of DNA satellite molecules of non-viral origin: beta satellites and alpha satellites. These satellites play a vital role in the suppression of host defense mechanisms, which leads to enhanced virulence of the virus. Enhanced virulence results in systemic infection and severe symptoms of disease [23].

Salicylic acid (SA) acts as a signaling hormone and provides a pathway for the activation of a defense reaction [24]. SA is an endogenous regulator that has a definite role in defense mechanisms against biotic and abiotic stresses [25]. The expression of PR genes is closely related to the exogenous application of SA and also confers resistance against various pathogens, such as viruses, bacteria and fungi $[26,27]$.

Benzothiadiazole (BTH) is a chemical analog of SA. It has been used effectively to induce resistance to an extensive variety of diseases affecting field crops [28]. BTH is a powerful systemic acquired resistance activator downstream from SA signaling. It increases crop resistance by activating systemic acquired resistance in many plant species, including bean, cauliflower, cucumber, tobacco, apple and pear [29]. BTH also induces resistance against geminivirus in pepper plants [30].

The resultant induction of the aforementioned enzymatic activity was determined through an easily modified microplate assay in which laminarin and colloidal chitin were used as substrates and reducing sugars were quantified by DNS reagent. This method would work as an alternative to cuvette-based macroassay, which is expensive and time-consuming.

\section{Methods}

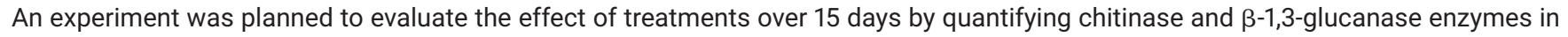
cotton plant leaves. The highly susceptible cotton variety CIM-496 was grown in a screen house measuring 600 sq $\mathrm{ft}$ in earthen pots measuring $12 \times 9 \times 6$ in. At four-leaf stage treatments, BTH (Sigma-Aldrich, MO, USA) and SA (Sigma-Aldrich) were exogenously applied with an atomizer at concentrations of $2.20 \mathrm{mM}$ (equal to $300 \mathrm{mg} / \mathrm{l}$ ) and $10 \mathrm{mM}$, respectively. The CLCuV Multan strain was inoculated using whiteflies (B. tabaci). Aviruliferous whiteflies were reared on CLCuV Multan strain-infected plants in BugDorm (MegaView Science Co., Ltd., TXG, TW) cages measuring $75 \times 75 \times 115 \mathrm{~cm}$ with nylon 150 mesh. There were three biological replicates of each treatment as well as three technical replicates of each treated sample. The samples were collected for analysis after $72 \mathrm{~h}$ of elicitor application and from virus-inoculated plants when disease symptoms appeared. The experiment was carried out twice with the same number of plants and treatments, and the data were compiled by taking the average of two independent experiments.

\section{Enzyme extraction}

Freshly detached cotton leaves $(1 \mathrm{~g})$ from treatments were vigorously homogenized using liquid nitrogen in a precooled pestle and mortar, followed by the immediate addition of $2 \mathrm{ml}$ of chilled 0.05-M sodium acetate buffer ( $\mathrm{pH} 5.0$ ), and transferred to a 1.5-ml centrifuge tube for centrifugation at $13,500 \times \mathrm{g}$ for $15 \mathrm{~min}$ at $4{ }^{\circ} \mathrm{C}$. The supernatant was used directly as an enzyme in the assay. For protein determination, leaves were extracted separately in sodium phosphate buffer ( $\mathrm{pH}$ 7.2). Total proteins were estimated using Bradford reagent and bovine serum albumin as the standard [31].

\section{Cuvette assay for $\beta-1,3-$ glucanase}

Laminarin (Sigma-Aldrich) and dinitrosalicylic acid methods [32] were used to determine $\beta$-1,3-glucanase activity. The reaction was prepared using a $4 \%$ laminarin and enzyme extract mixed in an equal volume of $62 \mu$ l, followed by incubation at $40^{\circ} \mathrm{C}$ for 10 min. The reaction was terminated by adding $375 \mu$ of DNS reagent. The reaction mixture was heated for 5 min in boiling water, and optical density was measured at $550 \mathrm{~nm}$ with a SmartSpec $3000 \mathrm{UV} /$ visible spectrophotometer (Bio-Rad Laboratories, Inc., CA, USA). Enzymatic activity was designated as $\mu \mathrm{g}$ glucose produced per min per mg of protein.

\section{Cuvette assay for chitinase}

Chitinase activity was measured using chitin from shrimp shells (Sigma-Aldrich) as substrate. Colloidal chitin was prepared according to the described method [33]. Sodium acetate buffer $50 \mathrm{mM}(\mathrm{pH} 6.0)$ was used to prepare a $1 \%$ solution of colloidal chitin, and $300 \mu \mathrm{l}$ was mixed in $1 \mathrm{ml}$ of enzyme sample, followed by an incubation of $30 \mathrm{~min}$ at $40^{\circ} \mathrm{C}$ [34]. The reaction was terminated by adding $600 \mu \mathrm{l}$ of DNS [35]. Insoluble chitin was removed by keeping the mixture in hot water for 20 min. After boiling, the resultant mixture was chilled 


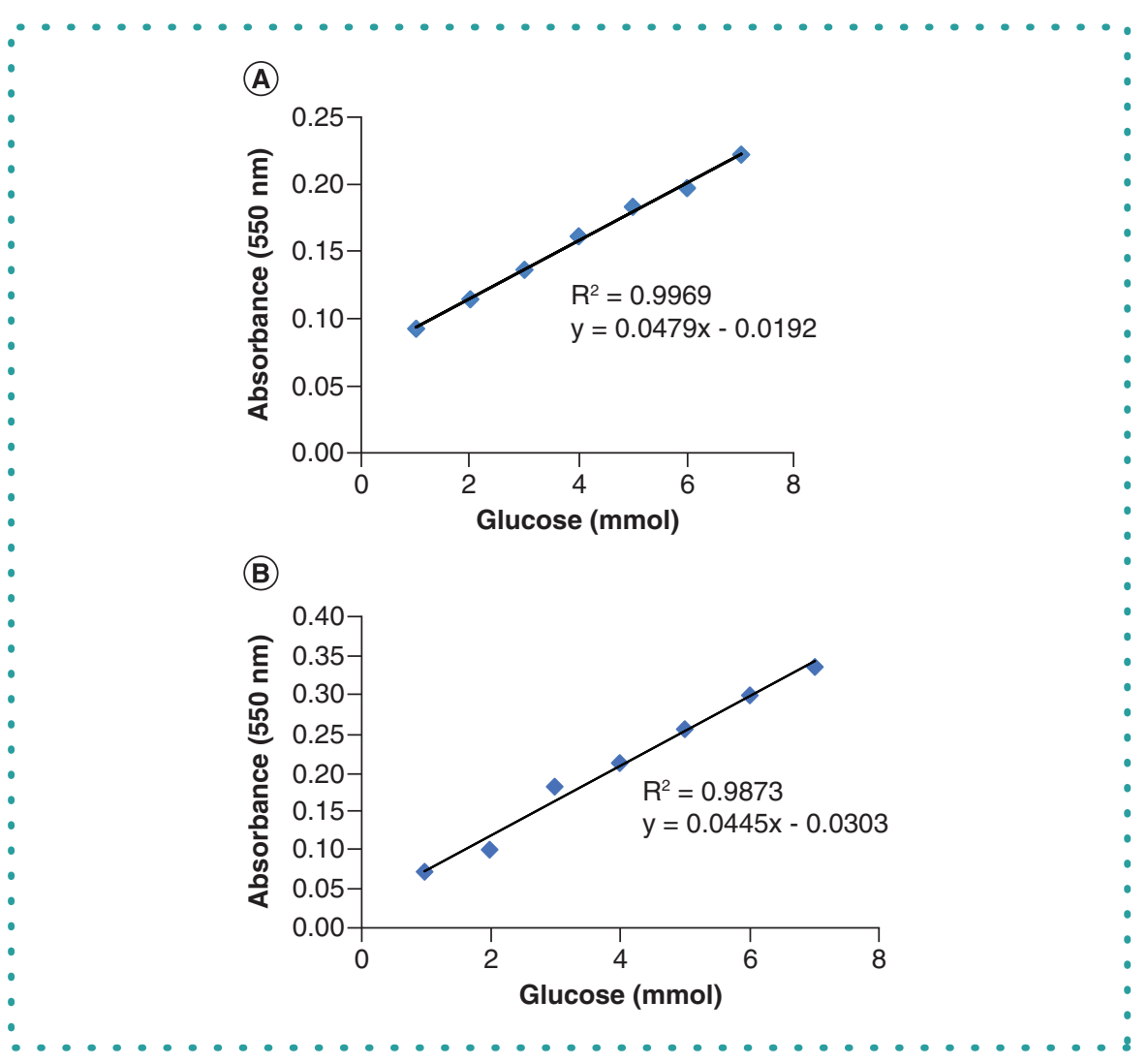

Figure 1. DNS standard curves for calculating released reducing sugars for (A) microplate assay and (B) cuvette assay. DNS: 3,5-dinitrosalicylic acid.

and centrifuged. The subsequent reducing sugars were calculated at $550 \mathrm{~nm}$ using a spectrophotometer [36]. Chitinase activity was designated as $\mathrm{U} \mathrm{mg}^{-1}$ of protein.

\section{Microplate-based assay}

Enzymatic production of chitinase and $\beta$-1,3-glucanase was estimated separately using $0.25 \%$ colloidal chitin and laminarin, respectively, as substrates. The reaction was prepared by mixing $20 \mu \mathrm{l}$ of each substrate solution with $10 \mu \mathrm{l}$ of enzyme extract. The mixture was added to a Multiplate 96-well non-skirted PCR plate (Bio-Rad Laboratories, Inc.) and sealed with Axygen ${ }^{\circledR}$ sealing film (Corning Life Sciences, AZ, USA). The PCR plate was incubated for $15 \mathrm{~min}$ at $40^{\circ} \mathrm{C}$ in a 96 -well MyCycler (Bio-Rad Laboratories, Inc.). After incubation, $1.3 \%$ phenol (Sigma-Aldrich), $20 \% \mathrm{Na}$-K-tartrate, $100 \mu \mathrm{l}$ of DNS reagent (Sigma-Aldrich) and $1.25 \% \mathrm{NaOH}$ were mixed and heated for $5 \mathrm{~min}$ at $95^{\circ} \mathrm{C}$. The prepared mixture was cooled at room temperature, and $100 \mu \mathrm{l}$ was added to a 96 -well microtiter ELISA plate. The absorbance of reduced sugars in the microplate was calculated at $550 \mathrm{~nm}$ using an ELX800 ELISA reader (BioTek Instruments, Inc., VT, USA). Enzymatic activity was calculated by the quantity of enzyme, which produced $\mu \mathrm{g}$ of reducing sugar per min per $\mathrm{mg}$ of protein under both sets of conditions.

\section{Glucose standard curve}

For the standard curve, scientific-grade glucose (Sigma-Aldrich) at a concentration of $750 \mu \mathrm{g} / \mathrm{ml}$ was added to non-skirted PCR plates in a quantity of $0,20,40,60$ and $80 \mu$ leach in three replicates. Water was added to make a volume of $100 \mu$, followed by the addition of $100 \mu \mathrm{l} \mathrm{DNS}$ reagent in reaction. Each plate was heated at $95^{\circ} \mathrm{C}$ for $5 \mathrm{~min}$ in a thermocycler. Each reaction was cooled to room temperature and transferred to a microtiter ELISA plate, and absorbance was measured at $550 \mathrm{~nm}$ in a spectrophotometer. The regression equation was derived from the standard curve (Figure 1).

The regression equation for microassay under the standard condition:

$$
Y=0.0479 X-0.0192
$$

$$
X=Y+0.0192 \div 0.0479
$$




\begin{tabular}{|c|c|c|c|c|}
\hline \multirow[t]{2}{*}{ Treatment } & \multicolumn{2}{|c|}{$\beta-1,3$-glucanase assay $\mathrm{U} \mathrm{mg}^{-1}$} & \multicolumn{2}{|c|}{ Chitinase assay $\mathrm{U} \mathrm{mg}^{-1}$} \\
\hline & Microassay & Cuvette assay & Microassay & Cuvette assay \\
\hline Control & $17.98 \pm 0.03 d$ & $9.27 \pm 0.81 \mathrm{c}$ & $108.67 \pm 0.40 c$ & $97.67 \pm 1.67 d$ \\
\hline Virus-inoculated & $30.75 \pm 0.71 c$ & $16.25 \pm 2.29 b$ & $148.67 \pm 1.02 b$ & $122 \pm 2.19 c$ \\
\hline $\mathrm{SA}(10 \mathrm{mM})$ & $37.83 \pm 0.40 b$ & $21.39 \pm 1.86 a b$ & $193 \pm 1.79 b$ & $145 \pm 2.90 b$ \\
\hline BTH (2.2 mM) & $42.99 \pm 0.57 a$ & $27.10 \pm 1.85 a$ & $194 \pm 1.81 a$ & $154 \pm 2.13 a$ \\
\hline \multicolumn{5}{|l|}{ Statistics } \\
\hline LSD value & 5.61 & 5.83 & 4.21 & 7.47 \\
\hline $\mathrm{CV}$ & 2.67 & 16.74 & 1.39 & 3.05 \\
\hline Chi-square & 8.8 & 1.56 & 3.93 & 0.49 \\
\hline$t$-value & 11.67 & 8.72 & 15.03 & 19.29 \\
\hline
\end{tabular}

Values significant at $p<0.05$. Means in each column with the same letter are not significantly different at $<0.05$.

BTH: Benzothiadiazole; CV: Coefficient of variation; LSD: Least significant difference; SA: Salicylic acid.

$$
\begin{aligned}
& \qquad \mathrm{Y}=\mathrm{OD}_{\text {Sample }}-\mathrm{OD}_{\text {Control }} \\
& \beta \text {-1,3-glucanase/Chitinase }(\mathrm{U} / \mathrm{mg})=\mathrm{X} \times \mathrm{SV} \div \mathrm{VSE} \times \mathrm{PC} \\
& \text { as put in Equation }(4) \text { and solved. } \\
& =(\mathrm{Y}+0.0192) \div 0.0479 \times \mathrm{SV} \div(\mathrm{VSE} \times \mathrm{PC}) \\
& =20.876 \times(\mathrm{Y}+0.0192) \times \mathrm{SV} \div(\mathrm{VSE} \times \mathrm{PC})
\end{aligned}
$$

The value of $X$ from Equation (2) was put in Equation (4) and solved.

Equation (5) was used for the calculation of $\beta-1,3-$ glucanase and chitinase activity in microassay.

The regression equation for cuvette assay under standard condition: $Y=0.0445 X-0.0303$

$$
X=Y+0.0303 \div 0.0445
$$

Putting the values in Equation (4).

$$
=22.47 \times(\mathrm{Y}+0.0303) \times \mathrm{SV} \div(\mathrm{VSE} \times \mathrm{PC})
$$

Equation (7) was used for the calculation of $\beta$-1,3-glucanase and chitinase activity in the macroassay. PC represents protein concentration, SV represents sample volume and VSE represents volume of sample enzyme..

\section{Statistical analysis}

The collected data set was statistically analyzed and subjected to analysis of variance and Duncan's multiple range test for the comparison of treatments, and least significant difference values were also calculated for minimum significant difference among treatments. Chi-square test and $t$-test were employed for the determination of statistically significant differences between the two procedures. All statistical analyses were performed using Statistix 8.1 software (Informer Technologies, Inc., FL, USA).

\section{Results \& discussion}

Enzymatic activity of $\beta-1,3$-glucanases and chitinases plays a crucial role in the defense mechanisms of plants. The quantification of this enzymatic activity requires an accurate and robust technique that produces reliable and efficient results. Many scientists have developed assays for the determination of these enzymes within plant and microbial preparations [16,37]. Here the authors optimized the modified microplate assay for the determination of $\beta-1,3-g l u c a n a s e$ and chitinase activity in cotton plants as a result of CLCuV infection and exogenous application of elicitors like BTH and SA. Therefore, the microplate-based method was optimized for only $\beta-1,3-g l u c a n a s e$ activity in Trichoderma spp. [37].

The authors' results showed a substantial increase in the enzymatic activity of $\beta-1,3-$ glucanase and chitinase in elicitor-treated as well as virus-inoculated cotton plants compared with control (Table 1). To estimate the enzymatic activity of $\beta-1,3-$ glucanase, the substrate laminarin was used at a concentration of $0.25 \%$ in a modified assay, which produced consistent results, whereas at higher concentrations 


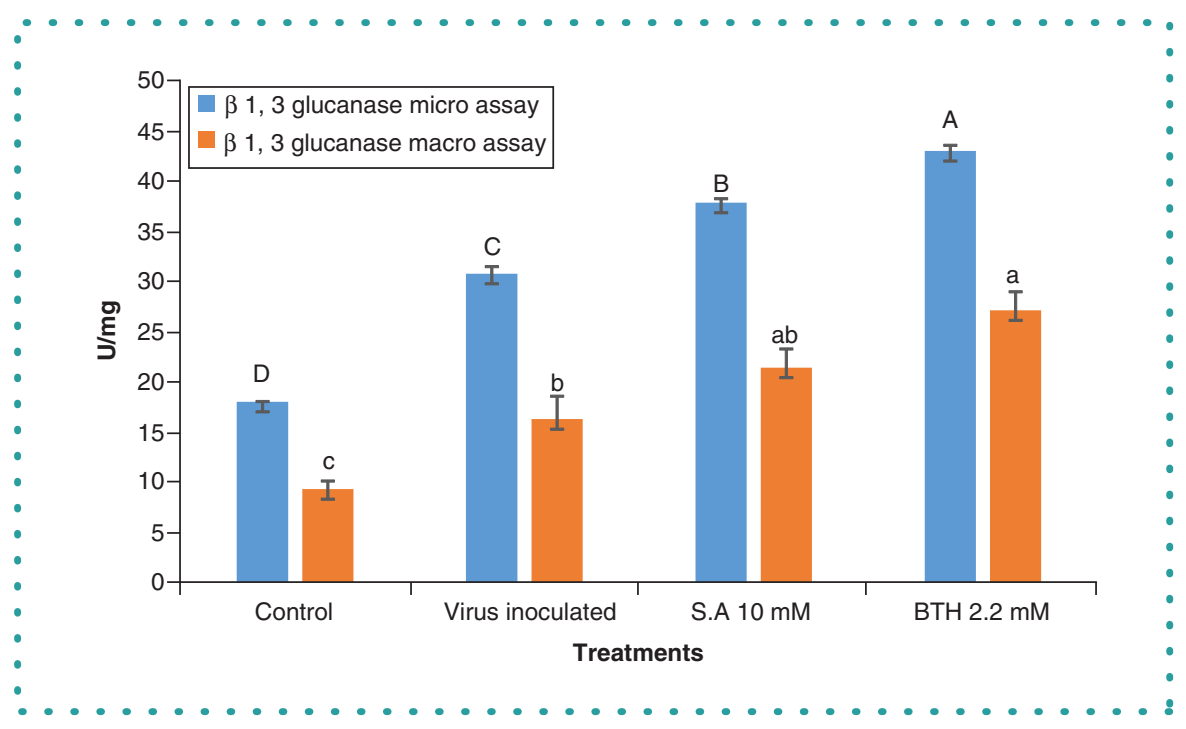

Figure 2. Comparison of $\beta-1,3-g l u c a n a s e$ activity of microassay (uppercase lettering) and macroassay (lowercase lettering). Different letters show a significant $(p=0.05)$ difference between the means.

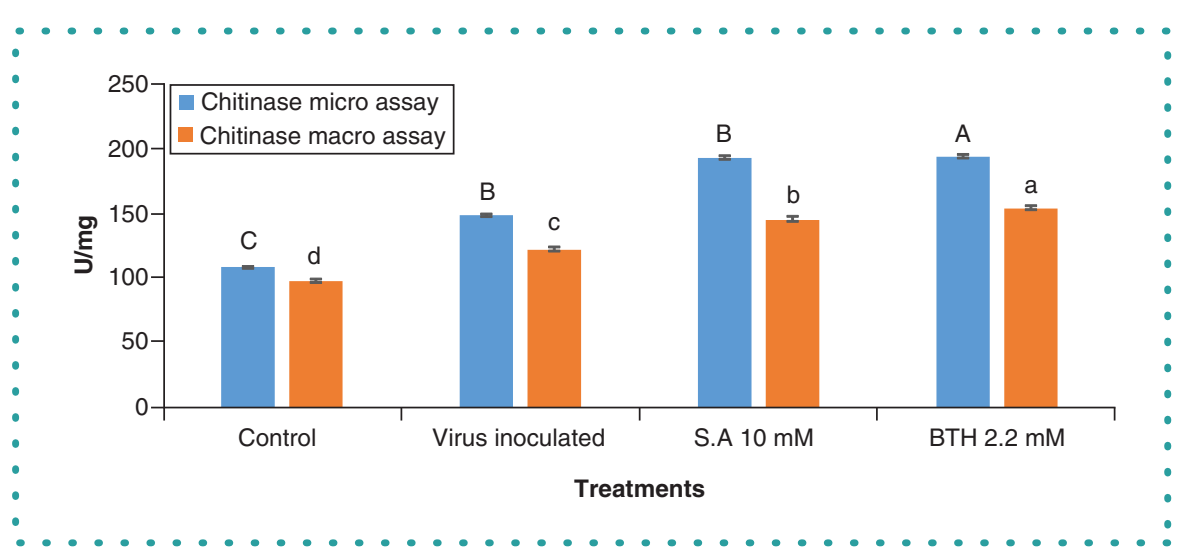

Figure 3. Comparison of chitinase activity of microassay (uppercase lettering) and macroassay (lowercase lettering). Different letters show a significant $(p=0.05)$ difference between the means.

(i.e., $0.75,1$ and $2 \%$ ), the results were not substantial enough to validate the increase in substrate concentration. To determine chitinase activity, the substrate colloidal chitin was also used at a concentration of $0.25 \%$ in this modified assay. Cuvette-based macroassay has been optimized with $4 \%$ laminarin for $\beta$-1,3-glucanase [32] and 1\% colloidal chitin for chitinase [34], and any decrease in concentration has been shown to affect the results of enzymatic activity. Further, the comparison of microplate assay with cuvette-based macroassay in the current study revealed a significant difference in enzymatic activity (Figures $2 \& 3$ ). Lower least significant difference and coefficient of variation values reflected the consistency of the microplate assay compared with the cuvette-based assay. Enzymatic assay sensitivity in the cotton plant was almost twofold greater when determined by microplate assay compared with macroassay (Table 1). Ramada et al. also found that the sensitivity of the microplate assay was twofold higher than that seen with macroassay when determining $\beta$-1,3glucanase activity in Trichoderma spp. [17]. Although the amount of chitinase produced was significantly higher in the microplate assay, the sensitivity was less than onefold higher than that seen with the cuvette-based macroassay.

Zheng and Wozniak devised a microplate assay to estimate $\beta-1,3-$ glucanase activity in the tobacco plant using $0.4 \%$ laminarin as substrate, and reducing sugars were subsequently quantified by copper reagent and neocuproine. Oxidation of reduced $\mathrm{Cu}+\mathrm{due}$ to interaction with air resulted in precipitation that altered the optical density [16]. In the authors' modified microplate assay, an aromatic compound (DNS reagent) was used to measure the reduced sugar without any precipitation problem when dealing with a large number of samples. Even $0.1 \%$ laminarin was used as substrate, but to estimate reducing sugars, aniline blue, $\mathrm{HCl}$ and $\mathrm{NaOH}$ were added to the reaction; after $1 \mathrm{~h}$, a stable sirofluor-laminarin complex was formed and determined by fluorimeter. However, in the authors' optimized assay, only DNS was used to measure the reducing sugars, and no complex was formed [38]. Similarly, for the estimation of chitinase, trichloroacetic acid was used to stop the precipitation formation, followed by centrifugation, which made the process lengthy [39]. 
The precipitation problem also persists with other substrates (i.e., dye-labeled polysaccharide derivatives like carboxymethyl-chitinRemazol Brilliant Violet 5R (CM-chitin-RBV) and CM pachyman-Remazole Brilliant Blue (CM-pachyman-RBB), which are used for chitin and 1,3- $\beta$-glucanase activity assays, respectively). The precipitation problem is overcome by the addition of $20 \% \mathrm{HCl}$, which separates non-degraded polymeric substrate from the reaction mixture before spectrophotometry [40]. This procedure is time-consuming and less sensitive because of precipitation.

The authors' optimized assay for the estimation of chitinase and $\beta-1,3-$ glucanase is inexpensive, rapid, robust, time-saving, sensitive and accurate when measuring a large number of samples. Along with the cost of laminarin and colloidal chitin, approximately 100 samples can be assayed for only US $\$ 2$. In other assays, one has to deal with precipitation problems, larger quantities of substrates and long incubation and centrifugation times, which makes them time-consuming, expensive and difficult when handling a large number of samples. Moreover, the authors' modified assay can be used for both microbial preparations and leaf samples that produce chitinase and $\beta$-1,3-glucanase.

\section{Conclusion}

Our modified and optimized microplate assay appears to be better, faster and more robust and economical than cuvette assay for the determination of $\beta-1,3$-glucanase and chitinase enzymatic activity induced in the cotton plant by viral infection or exogenous application of elicitors.

\section{Future perspective}

The enzymes $\beta$-1,3-glucanase and chitinase are classified as PR proteins and appear to play a crucial role in the defense mechanisms of plants against pathogens. When evaluating crop varieties for resistance against diseases based on the production of these enzymes, our technique could be utilized for the screening of large germplasms in a short period. Plant varieties with elevated activity of these enzymes could be incorporated into a breeding program for resistance against diseases.

\section{Author contributions}

M F Khan worked under the supervision of U Umar. U Umar contributed by conceiving the study, designing the experiments, analyzing the data and proofreading the manuscript. M F Khan contributed by performing all the experiments and drafting the manuscript. Both authors have read and approved the final manuscript.

\section{Acknowledgments}

The authors are thankful for the support of the Directorate of Research \& External Linkages, Bahauddin Zakariya University, Multan, Pakistan. The authors also appreciate and acknowledge M Nauman for helping with the bibliography.

\section{Financial \& competing interests disclosure}

This study was funded by Directorate of Research \& External Linkages, Bahauddin Zakariya University. The authors have no other relevant affiliations or financial involvement with any organization or entity with a financial interest in or financial conflict with the subject matter or materials discussed in the manuscript apart from those disclosed.

No writing assistance was utilized in the production of this manuscript.

\section{Open access}

This work is licensed under the Attribution-NonCommercial-NoDerivatives 4.0 Unported License. To view a copy of this license, visit http://creativecommons.org/licenses/by-nc-nd/4.0/

\section{References}

1. Grover A, Gowthaman R. Strategies for development of fungus-resistant transgenic plants. Curr. Sci. 84(3), 330-340 (2003).

2. Kasprzewska AN. Plant chitinases - regulation and function. Cell. Mol. Biol. Lett. 8(3), 809-824 (2003).

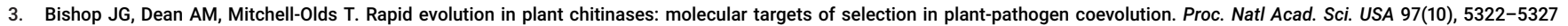
(2000).

4. Suslow TV, Jones J. Advanced Genetic Sciences Inc. OL, CA. In: Chitinase-producing bacteria. US Patent US 4,751,081 (1998).

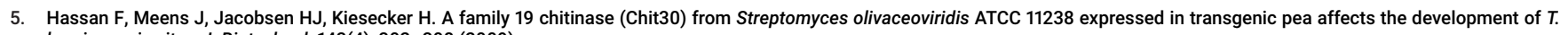
harzianum in vitro. J. Biotechnol. 143(4), 302-308 (2009).

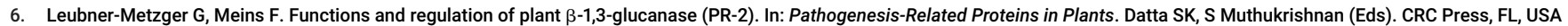
(1999).

7. Collinge DB, Slusarenko AJ. Plant gene expression in response to pathogens. Plant Mol. Biol. 9(4), 389-410 (1987).

8. Stone B, Clarke A. Chemistry and biology of (1,3)-b-glucans. In: (1,3,1,4)- $\beta$-Glucans in Higher Plants. La Trobe University Press, Victoria, Australia (1992).

9. Aist JR. Papillae and related wound plugs of plant cells. Ann. Rew. Phytopathol. 14(1), 145-163 (1976).

10. Shimomura T, Dijkstra J. The occurrence of callose during the process of local lesion formation. Neth. J. Plant Pathol. 81(3), 107-121 (1975).

11. Castresana C, de Carvalho F, Gheysen G, Habets M, Inzé D, Van Montagu M. Tissue-specific and pathogen-induced regulation of a Nicotiana plumbaginifolia beta-1, 3-glucanase gene. Plant Cell 2(12), 1131-1143 (1990).

12. Felix G, Meins F. Ethylene regulation of $\beta$-1,3-glucanase in tobacco. Planta 172(3), 386-392 (1987). 
13. Denault LJ, Allen W, Boyer E, Collins D, Kramme D, Spradlin JE. A simple reducing sugar assay for measuring $\beta$-glucanase activity in malt, and various microbial enzyme preparations. $J$. Ameri. Soci. Brew. Chem. 36(1), 18-23 (1978).

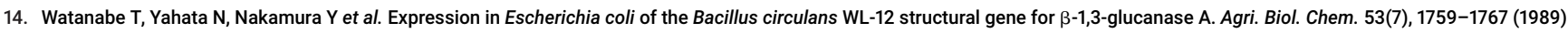

15. Dygert S, Li L, Florida D, Thoma JA. Determination of reducing sugar with improved precision. J. Anal. Biochem. 13(3), 367-374 (1965).

16. Zheng $Y$, Wozniak CA. Adaptation of a $\beta$-1,3-glucanase assay to microplate format. Biotechniques 22(5), $922-926$ (1997).

17. Ramada MHS, Lopes FÁC, Ulhoa CJ, do Nascimento SR. Optimized microplate $\beta$-1,3-glucanase assay system for Trichoderma spp. screening. J. Microbiol. Methods 81(1), 6-10 (2010).

18. Noe CR, Lachmann B, Möllenbeck S, Richter P. Determination of reducing sugars in selected beverages by capillary electrophoresis. Zeitschrift Für Lebensmitteluntersuchung undForschung A 208(2), 148-152 (1999).

19. Hu DY, Wan QQ, Yang S et al. Synthesis and antiviral activities of amide derivatives containing the $\alpha$-aminophosphonate moiety. J. Agri. Food Chem. 56(3), 998-1001 (2008).

20. Mansoor S, Bedford I, Pinner M, Stanley J, Markham PG. A whitefly-transmitted geminivirus associated with cotton leaf curl disease in Pakistan. Pak. J. Bot. 105-107 (1993).

21. Hameed S, Khalid S, Ehsan-ul-Haq S, Hashrni AA. Cotton leaf curl disease in Pakistan caused by a whitefly-transmitted geminivirus. Plant Dis. 78(5), 529 (1994).

22. Akhtar KP, Khan AI, Hussain M, Khan MS. Comparison of resistance level to cotton leaf curl virus (CLCuV) among newly developed cotton mutants and commercial cultivars. Plant Pathol. J. 18(4), 179-186 (2002).

23. Brown JK. Cotton leaf curl disease. In: Compendium of Cotton Diseases. Kirkpatrick TL, Rockroth CS (Eds). American Phytopathological Society, MN, USA, 52-54 (2001).

24. Ryals JA, Neuenschwander UH, Willits MG, Molina A, Steiner HY, Hunt MD. Systemic acquired resistance. Plant Cell 8(10), 1809 (1996).

25. Heil M, Bostock RM. Induced systemic resistance (ISR) against pathogens in the context of induced plant defences. Ann. Bot. 89(5), 503-512 (2002).

26. Malamy J, Hennig J, Klessig DF. Temperature-dependent induction of salicylic acid and its conjugates during the resistance response to tobacco mosaic virus infection. Plant Cell 4(3), 359-366 (1992).

27. Kogel KH, Beckhove U, Dreschers J, Munch S, Romme Y. Acquired resistance in barley (the resistance mechanism induced by 2,6-dichloroisonicotinic acid is a phenocopy of a genetically based mechanism governing race-specific powdery mildew resistance). Plant Physiol. 106(4), 1269-1277 (1994).

28. Washington WS, Engleitner S, Boontjes G, Shanmuganathan N. Effect of fungicides, seaweed extracts, tea tree oil, and fungal agents on fruit rot and yield in strawberry. Aust. J. Exp. Agric. 39(4), 487-494 (1999).

29. Brisset MN, Faize M, Heintz C et al. Induced resistance to Erwinia amylovora in apple and pear. Acta Hortic. 590, 335-338 (2002).

30. Trejo SD, García NMA, Rivera BRF. Benzothiadiazole (BTH) induces resistance to pepper golden mosaic virus (PepGMV) in pepper (Capsicum annuum L.). Biol. Res. 46(4), 333-340 (2013).

31. Bradford MM. A rapid and sensitive method for the quantitation of microgram quantities of protein utilizing the principle of protein-dye binding. Anal. Biochem. 72 , 248-254 (1976).

32. Pan SQ, Ye XS, Kuć J. Association of $\beta$-1,3-glucanase activity and isoform pattern with systemic resistance to blue mould in tobacco induced by stem injection with Peronospora tabacina or leaf inoculation with tobacco mosaic virus. Physiol. Mol. Plant Pathol. 39(1), 25-39 (1991).

33. Wen CM, Tseng CS, Cheng CY, Li YK. Purification, characterization and cloning of a chitinase from Bacillus sp. NCTU2. Biotechnol. Appl. Biochem. 35(3), 213-219 (2002).

34. Ulhoa CJ, Peberdy JF. Purification and some properties of the extracellular chitinase produced by Trichoderma harzianum. Enzyme Microb. Technol. 14(3), 236-240 (1992).

35. Nelson N. A photometric adaptation of the Somogyi method for the determination of glucose. J. Biol. Chem. 153(2), 375-380 (1944).

36. Miller GL. Use of dinitrosalicylic acid reagent for determination of reducing sugar. Anal. Chem. 31(3), 426-428 (1959).

37. Ramada MHS, Lopes FÁC, Ulhoa CJ, do Nascimento SR. Optimized microplate $\beta$-1,3-glucanase assay system for Trichoderma spp. screening. J. Microbiol. Methods 81(1), 6-10 (2010).

38. Schraudner M, Ernst D, Langebartels C, Sandermann H. Biochemical plant responses to ozone: III. Activation of the defense-related proteins $\beta-1,3-g l u c a n a s e$ and chitinase in tobacco leaves. Plant Physiol. 99(4), 1321-1328 (1992).

39. Boller T, Gehri A, Mauch F, Vögeli U. Chitinase in bean leaves: induction by ethylene, purification, properties, and possible function. Planta 157(1), 22-31 (1983).

40. Wirth SJ, Wolf GA. Dye-labelled substrates for the assay and detection of chitinase and lysozyme activity. J. Microbiol. Methods 12(3-4), 197-205 (1990). 